\title{
PERKEMBANGAN MATERIAL ROTAN DAN PENGGUNAAN DI DUNIA DESAIN INTERIOR
}

\author{
Grace Hartanti \\ School Of Design, Jurusan Desain Interior, Universitas Bina Nusantara, \\ Jln. K.H. Syahdan No.9, Palmerah, Jakarta Barat 11480 \\ gracehartanti@yahoo.com
}

\begin{abstract}
For most Indonesia people, rattan had long been known, for personal use and trade. It started from raw materials and semi-finished trades, and later it was developed into the finished rattan product trade conducted by the wholesalers in Indonesia. In addition to the processing of rattan in Indonesia, the rattan finished-product trade has also been done widely.The trade agreement that has been made with foreign parties spur the contribution in increasing the state revenue which deserves to be taken into account. In this case, rattan application has grown in the world of Interior Design, for example as furniture and as interior accessories. The use of substitute materials, such as synthetic rattan, is now also widely used to fulfill high demand and product diversity. With the growing numbers of variants of rattan application in interior design field, a research based on qualitative research was applied. Article explores the process of research and rattan is expected to be the mediator in bringing local Indonesian culture to the global world competition. Thus, the state gait could be known more widely, and hopefully could help improving the welfare of Indonesian people into a better place.
\end{abstract}

Keywords: rattan, synthetic rattan, interior design.

\begin{abstract}
ABSTRAK
Bagi kebanyakan masyarakat di Indonesia, rotan sudah sejak lama dikenal. Selain untuk pemakaian sendiri, rotan juga sudah lama diperdagangkan dari perdagangan bahan mentah, setengah jadi, dan yang kemudian berkembang menjadi perdagangan hasil rotan jadi yang dilakukan oleh pedagang besar di Indonesia. Selain kegiatan pengolahan rotan, perdagangan rotan juga telah banyak dilakukan. Terjalinnya hubungan dagang dengan pihak luar negeri memacu bertambahnya peran hasil rotan untuk meningkatkan kontribusi penerimaan negara yang layak untuk diperhitungkan. Dalam hal ini pengaplikasian material rotan juga berkembang dalam dunia Desain Interior seperti contohnya pada penerapan dalam furniture dan accessories. Penggunaan material subsitusi seperti rotan sintetis kini juga banyak digunakan guna peningkatan permintaan dan keanekaragaman produk. Dengan berkembangnya pengaplikasian material rotan yang merupakan salah satu sumber hayati Indonesia dalam dunia desain interior, maka dilakukan penelitian yang menerapkan metode kualitatif studi literatur. Artikel menjelaskan proses penelitian yang diharapkan dapat menjadi mediator dalam membawa budaya lokal Indonesia ke tengah persaingan global sehingga kiprah bangsa lebih dikenal luas dan kesejahteraan masyarakat Indonesia dapat mengarah kekehidupan sosial ekonomi yang lebih baik lagi.
\end{abstract}

Kata kunci : rotan, rotan sintetis, desain interior 


\section{PENDAHULUAN}

Rotan asalnya merupakan tumbuhan yang tergolong dalam kelompok palem-paleman yang hidupnya merambat. Golongan ini termasuk dalam sub-famili calamoideae yang mempunyai 13 marga dan sekitar 600 jenis hidup pada kawasan hutan hujan tropis di Asia Tenggara. Kelompok rotan pada umumnya tumbuh dan dijumpai pada daerah yang beriklim basah. Di Indonesia, jenis ini dapat ditemui di Jawa, Kalimantan, Sulawesi dan beberapa kepulauan lainya. Beberapa laporan menyebutkan bahwa di Jawa dapat dijumpai sekitar 25 jenis, Sumatera 75 jenis, Kalimantan 100 jenis, dan Sulawesi mencapai 25 jenis. Selain itu rotan juga dapat dijumpai di beberapa pulau lainnya di Indonesia. Disini dapat dilihat, Indonesia memiliki sumber daya alami yang cukup kuat untuk material rotan.

Lebih dari 50 jenis rotan yang sudah dimanfaatkan dan diperdagangkan di Indonesia, ternyata baru sebagian kecil yang diekspor; antara lain rotan manau, rotan tohiti, rotan irit, rotan sega, rotan semambu, rotan pulut putih, rotan pulut merah yang semua ini termasuk dalam kelompok calamus. Saat ini rotan sudah dapat disebut sebagai komoditi yang mulai dapat diandalkan untuk penerimaan negara. Selain itu juga dipandang sebagai komoditi perdagangan hasil hutan non-kayu yang cukup penting bagi Indonesia. Produk rotan juga telah menambah penerimaan ekspor unggulan selain minyak dan gas bumi, serta dapat disejajarkan dengan penerimaan ekspor utama pertanian lainnya seperti kopi, karet dan minyak sawit. Dalam pengolahannya juga telah memperlihatkan daya saing yang tinggi. Desain yang ada sudah cukup berkembang dari bentuk furniture, accessories, alat olahraga dan beberapa bentuk produk lain.

Namun, untuk bertahan dalam persaingan global tetap perlu ditingkatkan lagi kreativitas Sumber Daya Manusia dalam mengolah material rotan. Disinilah diperlukan peranan serius pemerintah dan instansi lain yang terkait di daerah, sebagaimana perhatian yang selama ini telah diberikan kepada produk hasil hutan lainnya terutama seperti material kayu (sebagaimana diketahui kayu masih dipakai sebagai barometer keberhasilan ekspor hasil hutan Indonesia).

Kebijakan pengelolaan sumber daya hutan termasuk rotan sampai sekarang masih mengacu pada ketentuan pengelolaan kehutanan yang tertuang dalam Undang-undang Pokok Kehutanan tahun 1967. Kebijakan pemanfaatan ini belum mengantarkan kepada perhatian yang khusus sebagaimana perhatian kepada kayu. Rotan masih ditempatkan sebagai produk hutan sampingan sebagaimana dikenal dengan istilah "minor forest product".

Pengolahan rotan yang dilakukan oleh sebagian besar masyarakat di Indonesia terutama bagian pedalaman atau daerah pada umumnya masih tergolong sederhana. Kurangnya pemahaman mengenai kebiasaan masyarakat dalam membudidayakan rotan, ditambah belum cukupnya perhatian yang diberikan oleh pemerintah kepada masyarakat di pedalaman atau daerah, terutama untuk kegiatan pengumpulan rotan dan pengolahannya, menyebabkan kebijakan pemerintah belum dapat memberikan hasil yang memuaskan di lapangan.

Pemanfaatan hasil rotan alam dan rotan tanaman cukup berpeluang untuk meningkatkan penerimaan ekspor. Beberapa perubahan kebijakan pemerintah yang dilakukan akhir-akhir ini telah memberikan harapan bagi peningkatan penerimaan ekspor rotan Indonesia, sebagaimana dilaporkan bahwa ternyata hasilnya telah menempatkan Indonesia menjadi ekportir produk rotan yang cukup berhasil pada tahun 1991.

Diharapkan perbaikan-perbaikan yang ada dari berbagai aspek seperti kebijakan-kebijakan pemerintah, kreativitas masyarakat dalam mengolah dan memasarkan produk berbahan dasar rotan baik mentah, setengah jadi, dan jadi dapat terus membawa kemajuan kearah yang lebih baik bagi kemajuan Bangsa Indonesia dalam kiprahnya di era globalisasi. 


\section{METODE}

Penelitian menggunakan metode kualitatf dengan model studi kepustakaan, khususnya mencari informasi tentang sejarah rotan di Indonesia, populasi, penyebaran rotan, manfaat rotan, pengolahan, pembuatan rotan sintetis, dan perdagangan rotan.

\section{HASIL DAN PEMBAHASAN}

\section{Penyebaran Rotan}

Rotan berasal dari bahasa Melayu yang berarti nama dari sekumpulan jenis tanaman famili Palmae yang tumbuh memanjat yang disebut "Lepidocaryodidae". Lepidocaryodidae berasal dari bahasa Yunani yang berarti mencakup ukuran buah. Kata rotan dalam bahasa Melayu diturunkan dari kata "raut" yang berarti mengupas (menguliti), menghaluskan.

Rotan dalam struktur dunia tumbuh-tumbuhan termasuk Divisio Spermatophyta, sub divisio Angiospermae, class Monocotyledonae, Ordo Spacadiciflorae dan Famili/suku Palmae, dimana sampai saat ini sudah dikenal sebanyak 15 suku yaitu: Calamus, Daemonorops, Khorthalsia, Plectocomia, Ceratolobus,Plectocomiopsis, Myrialepis, Calospatha, Bejaudia, Cornera, Schizospatha, Eremospatha, Ancitrophylum dan Oncocalamus.Dari jumlah suku yang telah ditemukan tersebut, telah diketahui sebanyak 9 suku dengan jumlah jenisnya, yaitu : Calamus (370 spp/jenis), Daemonorops (115 spp/jenis), Khorthalsia (31 spp/jenis), Plectocomia (14 spp/jenis), Ceratolobus (6 spp/jenis), Plectocomiopsis (5 spp/jenis), Myrialepis (2 spp/jenis), Calospatha (2 spp/jenis), dan Bejaudia (1 spp/jenis).

Di Indonesia sampai saat ini ditemukan sebanyak 8 jenis, yaitu Calamus, Daemonorops, Khorthalsia, Plectocomia, Ceratolobus, Plectocomiopsis, Myrialepis, dan Calospatha. Dari 8 suku tersebut total jenisnya di Indonesia mencapai tidak kurang dari 306 jenis, penyebarannya di pulau Kalimantan sebanyak 137 jenis, Sumatera sejumlah 91 jenis, Sulawesi menyebar sebanyak 36 jenis, Jawa sejumlah 19 jenis, Irian 48 jenis, Maluku 11 jenis, Timor 1 jenis dan Sumbawa 1 jenis. Berdasarkan data Departemen Kehutanan, menunjukan bahwa Propinsi Kalimantan Tengah merupakan daerah yang memiliki populasi pohon rotan yang tertinggi di Indonesia dengan populasi mencapai $75,45 \%$ dari total $\pm 17,6$ juta pohon dan jumlah pohon yang siap tebang mencapai $81,10 \%$ dari total $\pm 14,7$ juta pohon rotan. Data sebaran potensi populasi dan prosentase pohon rotan tersebut diikuti oleh Propinsi Kalimantan Timur dengan jumlah 13,69 \% dan 8,66 \% dan Kalimantan Selatan dengan jumlah 7,46 \% dan 8,28 \%, sedangkan sisanya tersebar dibawah prosentase $1 \%$ di seluruh wilayah propinsi lainnya. 


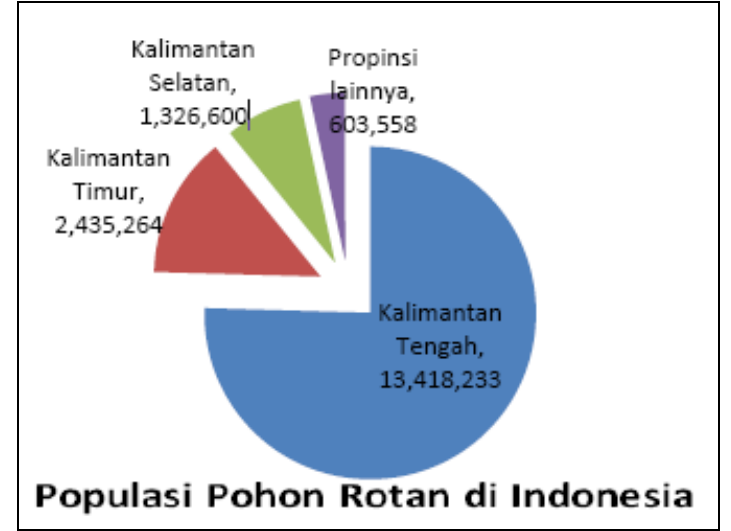

Gambar 1. Populasi Pohon Rotan di Indonesia

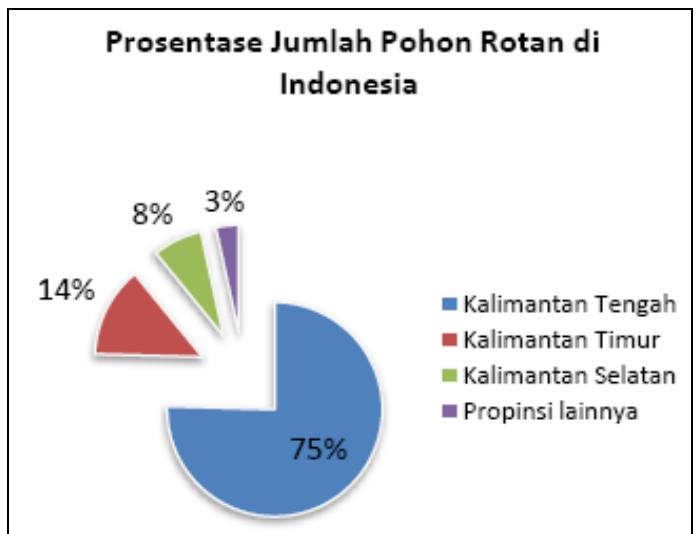

Gambar 2. Prosentase Jumlah Pohon Rotan di Indonesia

Dengan data tersebut, maka menjadi realistis apabila kebijakan tata niaga rotan yang dikeluarkan oleh Pemerintah Pusat harusnya berpihak pada daerah penghasil rotan, terutama tertuju pada para petani atau rumah tangga yang menguasai tanaman rotan, yang telah bertahun-tahun melakukan penanaman dan pemeliharaan tanaman rotan.

\section{Pengenalan Rotan}

Sampai saat ini jumlah rotan yang benar-benar diketahui memiliki sifat yang memenuhi syarat serta kualitas yang dipersyaratkan untuk berbagai penggunaan berjumlah 50 jenis. Dari jumlah tersebut yang benar-benar memiliki nilai komersial tinggi dan banyak dipungut dan kemudian diolah menjadi bahan baku mebel dan kerajinan baru berkisar 26 jenis saja.

Bagi masyarakat yang tinggal disekitar hutan, rotan selalu identik dengan sejenis tumbuhan yang tumbuh dan menjalar diantara batang pohon untuk tumbuh memanjang menjangkau langit dengan batang secara keseluruhan dibaluti oleh pelepah yang memiliki duri-duri tajam. Dibanding dengan tumbuhan dari suku Palmae lainnya, maka rotan memiliki berbagai keunikan yang tidak tertandingi dan tergantikan manfaat dan kegunaanya. Tumbuhan rotan yang batangnya hanya sebesar telunjuk tangan atau kalau pun lebih, maka besarnya rata-rata sebesar ibu jari kaki saja, namun panjangnya dapat menjulang melebihi tumbuhan lainnya, dimana panjangnya bisa mencapai 100 meter, bahkan lebih. Selain itu, dari segi bentuknya tumbuhan rotan juga tidaklah menarik, karena sebagian besar batangnya dibaluti oleh berbagai bentuk duri yang tajam sehingga akan kurang menarik dijadikan tanaman hias. Akan tetapi dibalik pelepah yang penuh duri itulah tersimpan keunikan, keuletan, kekenyalan yang tidak dimiliki oleh tumbuhan lainnya. Di mana keunikan dan kelebihan tersebut apabila dipadukan dengan daya kreasi dan imajinasi akan menghasilkan berbagai produk yang hasilnya telah mengisi dan menghiasi jutaan rumah tangga di seputar 80 negara di dunia.

Dalam hal memenuhi kebutuhan untuk menyediakan permintaan dunia akan keperluan produk rotan, negara kita pun tak diragukan karena sudah sejak abab ke-18 selalu menjadi pelopor dalam menyediakannya, di mana hampir 80\% keperluan akan rotan dunia di pasok oleh Indonesia, sekaligus pula mendapat pengakuan sebagai penghasil rotan terbaik yang mendominasi penggunaan rotan dunia.

Mengingat sampai saat ini produk bahan mentah rotan alam kita dipasaran International tidak memiliki pesaing yang berarti di satu pihak dan di lain pihak permintaan dunia akan rotan setiap tahunnya masih memiliki peluang untuk dapat dikembangkan pasarnya, maka adanya langkah untuk merintis pengembangan usaha pengolahannya nampaknya tidak akan mengalami kesulitan yang berarti. 


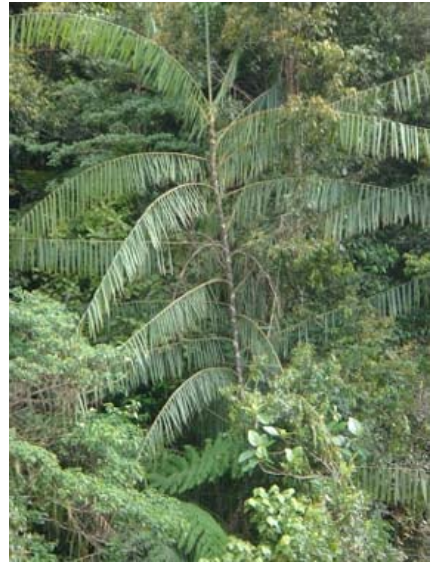

Gambar 3. Tanaman Rotan 1

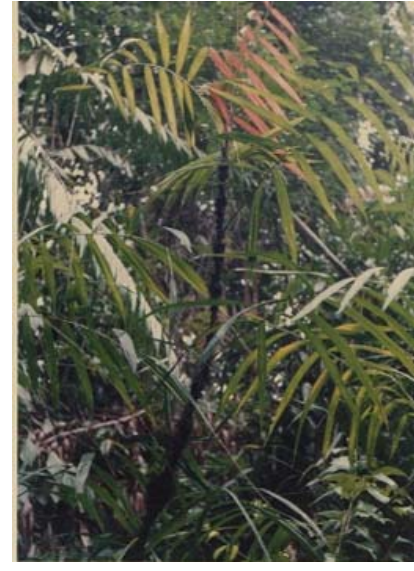

Gambar 4. Tanaman Rotan 2

Peradaban manusia khususnya masyarakat Indonesia sudah sejak lama mengenal dan menggunakan rotan dalam berbagai keperluan hidupnya sehari-hari, bahkan dibeberapa tempat bahan rotan telah menjadi pendukung perkembangan budaya masyarakat setempat. Sampai saat ini tidak pernah diketahui secara pasti sejak kapan awal dimulainya pertama kali kebiasaan atau budaya masyarakat Indonesia, dalam pemanfaatan rotan dengan segala produknya bagi mendukung perilaku, budaya dan keperluan keseharian masyarakat disekitar hutan.
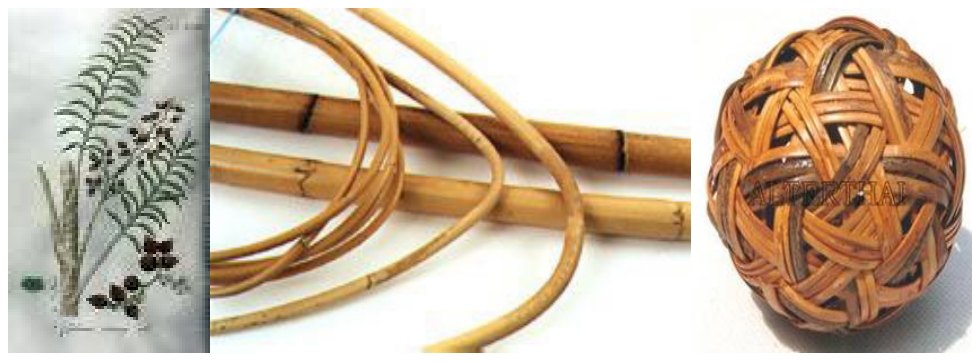

Gambar 5.Tumbuh alami di hutan, dipanen, diolah menjadi bahan sederhana seperti bola sepak takraw.

Pada awal sejarah penggunaanya rotan dimanfaatkan bukan saja karena jenis tanaman rotan merupakan jenis tanaman yang memiliki keunikan dan ciri khas yang berfungsi sebagai tali pengikat yang ulet dan kokoh yang ternyata tidak dimiliki oleh jenis tumbuhan lainnya. Ada banyak perbedaan dalam hal penggunaan tumbuhan rotan di masa lalu dengan saat ini, namun yang pasti perbedaan itu terletak dalam manfaat dan peranannya bagi mendukung kehidupan dan kesejahteraan manusia.

Pada masa lalu terbatasnya penggunaan rotan oleh penduduk lokal disebabkan karena tingkat pengetahuan, keperluan dan kreativitas masyarakat pada saat itu belum berkembang seperti saat ini, ditambah dengan belum meningkatnya kebutuhan akan keperluan berbagai bahan olahan dari rotan itu sendiri. Hal itu menyebabkan kegiatan untuk memproduksinya secara lebih besar dan ekonomis belum banyak dilakukan, terlebih untuk mata dagangan. Lebih dari itu pula, rotan yang kalau pada awal sejarah penggunaannya dipakai hanya terbatas bagi keperluan bahan tali pengikat dan bahan pembuatan alat penangkap ikan, maka akibat perubahan sikap, minat, perilaku serta perkembangan ekonomi, kini rotan telah berkembang begitu beragam kegunaan dan manfaatnya. Kegunaan dan manfaat rotan secara langsung antara lain bukan saja yang dihasilkan dari batangnya, tetapi juga bentuk tumbuhan lainya seperti buah, akar dan daunnya. 


\section{Pemanfaatan Rotan}

Manfaat langsung yang paling berarti dari produk yang dihasilkan tumbuhan rotan adalah berasal dari batangnya, baik dari batang yang sudah tua maupun bagian batang yang muda berupa umbutnya. Selain itu manfaat lainnya berasal dari buah, akar dan daunnya.

Selain batangnya, tumbuhan rotan memberikan hasil manfaat dari buah atau biji, daun bahkan akarnya. Manfaat itu antara lain untuk keperluan bahan baku kerajinan dan kontruksi bangunan. Umbutnya dapat dikonsumsi sebagai sayuran, kemudian akar dan buahnya dapat dijadikan sebagai obat tradisional. Sementara getah yang dihasilkan dari buah rotan Jernang sudah sejak lama dijadikan bahan untuk memenuhi keperluan bahan baku pewarnaan pada industri keramik dan industri farmasi.

Setiap bagian dari batang rotan mempunyai kegunaan yang beragam tergantung dari jenis hasil olahannya, antara lain: Rotan bulat /ketam/ amplas (polished), kegunaanya adalah untuk kerangka dalam pembuatan kursi, meja, tangkai payung, tangkai sapu, dan lainnya. Pemanfaatannya sendiri tergantung dari bentuk batang, diamater batang, warna, kilap, keawetan, kelurusan, dan panjang ruasnya. Kulit rotan (peel) digunakan untuk berbagai jenis anyaman (webbing), lampit, tikar, tas, keranjang, dan sebagai bahan pengikat. Pemanfaatannya didasari pada pada warna, elastisitas/ kekuatan, dan kelurusan bukunya. Hati rotan, manfaatnya untuk berbagai bahan pembuatan perabotan keranjang dan tali pengikat. Pengggunaannya didasarkan pada elastisitas, tingkat keawetannya, serta kehalusan hasil serutan dan ada tidaknya cacat. Limbah yang dihasilkan dari proses pengolahan kulit dan hati rotan, masih dapat dimanfaatkan bagi memenuhi keperluan industri petasan, pengisian jok mobil/kursi, dan lainnya.

\section{Pengolahan Rotan}

Pengolahan rotan adalah pengerjaan lanjutan dari rotan bulat (rotan asalan) menjadi barang setengah jadi dan barang jadi (Gambar 6) atau siap dipakai atau dijual. Pengolahan dalam industri yaitu proses pemisahan rotan bulat menjadi bagian-bagian rotan seperti kulit dan hati, masing-masing bagian tersebut diolah lagi sesuai tujuan dan pemanfaatannya. Pengolahan rotan terdiri pengolahan rotan berdiameter kecil $(<18 \mathrm{~mm})$ dan rotan berdiamerter besar $(>18 \mathrm{~mm})$.

Rotan yang berdiameter kecil seperti rotan seel (Daemonorop melanochaetes Becc.), yang telah dipanen dan dibersihkan untuk daun, duri, dan anggota batangnya yang kemudian dilakukan penggosokan dengan mengunakan serbuk gergaji atau sabut kelapa. Lalu rotan tersebut dipotongpotong sesuai standarnya dan dibawa ke tempat penumpukan rotan, kemudian dijemur sampai kering dan juga dilakukan pengasapan. Pengasapan pada dasarnya adalah proses oksidasi belerang (gas SO2) agar warna kulit rotan kuning merata dan tahan terhadap serangan jamur. Proses pengolahan sampai tahap ini disebut rotan WS (Washed and Sulphurized). Kemudian rotan tersebut dijemur.

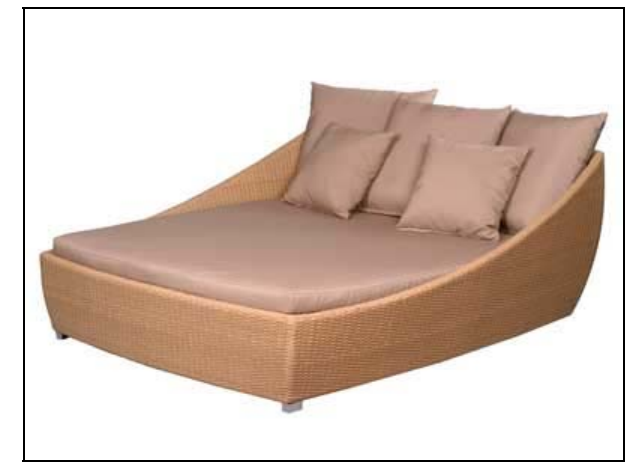

Gambar 6. Produk Barang Jadi dari Rotan 
Rotan yang sudah kering, dilakukan pembelahan (rotan dibelah) dan juga ada yang diambil kulitnya, digunakan untuk pengikat atau dibuat lampit. Rotan juga bisa diambil hatinya saja, kalau ukurannya besar disebut cor rotan dan kalau ukuran lebih kecil disebut fitrit dan rotan ini digunakan untuk barang kerajinan. Penggorengan rotan bertujuan menurunkan kadar air agar cepat kering dan juga untuk mencegah terjadinya serangan jamur. Cara penggorengannya adalah potongan-potongan rotan tersebut diikat menjadi suatu bundelan, kemudian dimasukkan ke dalam wadah yang sudah disiapkan campuran solar dengan minyak kelapa.

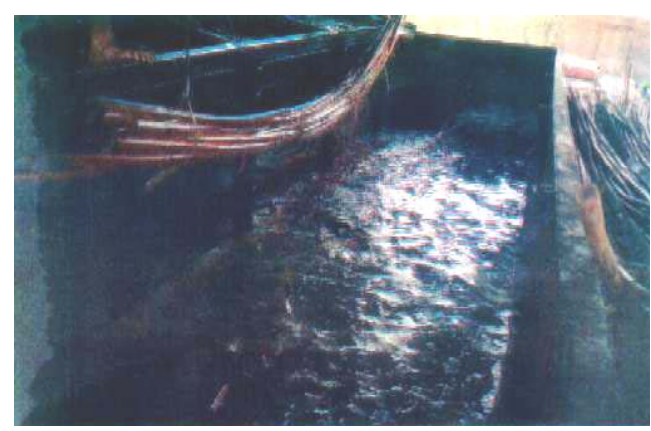

Gambar 7. Tungku dan Tempat Penggorengan Rotan

Setelah rotan digoreng, ditiriskan beberapa menit, kemudian digosok dengan kain perca (sabut kelapa) atau karung goni yang dicampur dengan serbuk gergaji, agar sisa kotoran terutama getah yang masih menempel pada kulit rotan dapat dilepaskan, sehingga kulit rotan menjadi bersih dan akan menghasilkan warna rotan yang cerah dan mengkilap. Setelah digoreng rotan dicuci dengan air bersih sambil digosok dengan sabut kelapa untuk membersihkan kotoran yang melekat pada batang.

Setelah rotan dicuci lalu dikeringkan dengan cara dijemur pada panas matahari sampai kering dengan kadar air berkisar 15\% - 19\%.

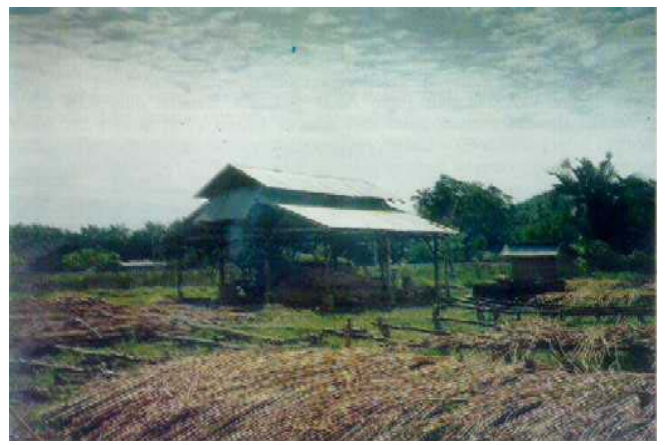

Gambar 8. Rotan yang Sudah Digoreng Kemudian Dijemur dan Dikeringkan

Pengupasan dan pemolisan umumnya dilakukan pada rotan besar pada keadaan kering, gunanya adalah untuk menghilangan kulit rotan tersebut, sehingga diameter dan warna menjadi lebih seragam dan merata. Pembengkokan atau pelengkungan rotan dilakukan pada rotan berdiameter besar sesuai dengan pengunaannya. Cara pembengkokan ini dilakukan dengan cara rotan tersebut dilunakkan dengan uap air panas yang disebut steaming dengan tabung berbentuk silinder (steamer) agar jaringan rotan menjadi lunak sehingga mudah dibengkokan. Biasanya pada proses tersebut sering terjadi beberapa kerusakan seperti pecah, patah, dan putusnya serat pada bagian permukaan yang dilengkungkan. 


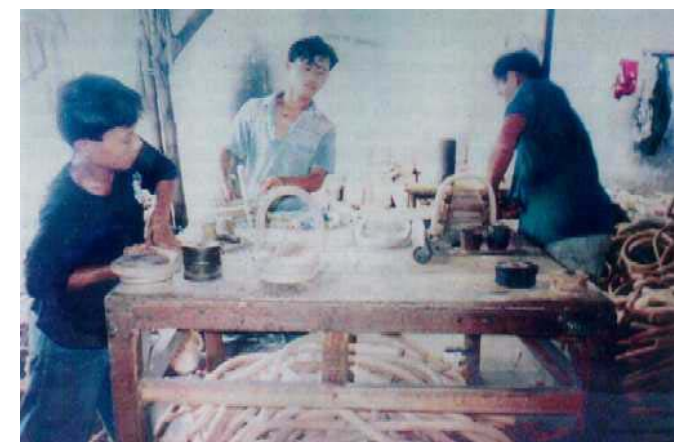

Gambar 9. Alat Untuk Membengkokkan Rotan.

Pemutihan rotan bertujuan menghilangkan silika, mengurangi kromofort (gugus penyebab warna) oksidasi terhadap struktur aromatik dari lignin dan karbohidrat (dalam kalium hipoklorit). Pemutihan perlu dilakukan, dan harus diperhatikan bahan yang dipakai, karena pemakaian bahan dan cara yang salah mengakibatkan rotan rusak (mudah patah).

Pengasapan dilakukan agar warna rotan menjadi kuning merata dan mengkilap. Pengasapan dilakukan pada rotan kering yang masih berkulit (alami). Pengasapan pada dasarnya adalah proses oksidasi rotan dengan belerang (gas SO2) agar warna kulit rotan menjadi lebih putih. Pengasapan dilakukan dalam rumah asap yang berbentuk kubah terbuat dari tembok dan balok kayu. Di dalam kubah dapat disusun 4000 batang rotan secara horizontal berlapis-lapis. Setiap lapisan diberi bantalan kayu agar asap bergerak bebas di antara lapisan rotan. Selanjutnya belerang dibakar di atas suatu wadah dan dimasukkan ke dalam rumah asap. Waktu pengasapan sekitar 12 jam dan menghabiskan sekitar 7,5 $\mathrm{kg}$ belerang atau 1,8 gr/batang rotan.

Pengawetan rotan adalah proses perlakuan kimia atau fisis terhadap rotan yang bertujuan meningkatkan masa pakai rotan. Bahan kimia untuk mengawetkan rotan disebut bahan pengawet. Selain berfugsi untuk mencegah atau memperkecil kerusakan rotan akibat oganisme perusak, juga memperpanjang umur pakai rotan.

Bahan pengawet yang digunakan harus bersifat racun terhadap organisme perusak baik pada rotan basah maupun rotan kering, permanen dalam rotan, aman dalam pengangkutan dan penggunaan, tidak bersifat korosif, tersedia dalam jumlah banyak dan murah.

Pengawetan mulai dilakukan pada rotan masih berdiri atau rotan sebelum dipungut (Bucheri), pengawetan rotan setelah panenan (propilaktik) dan pengawetan rotan setelah kering (permanen). Cara pengawetan seperti ini disesuaikan dengan organisme perusak rotan tersebut.

\section{Rotan Sintetis}

Rotan sudah lama dikenal sebagai bahan baku pembuatan furniture, accessories, serta perlengkapan dan peralatan lainnya. Namun rotan cenderung mempunyai kelemahan, yaitu tidak terlalu bersahabat dengan cuaca. Ini menyebabkan furniture, accessories, serta perlengkapan dan peralatan lain yang terbuat dari rotan kurang cocok ditempatkan di luar ruangan, meski akan nampak sangat natural jika diletakkan di taman. Ditambah lagi hama hewan yang suka bersarang di sela-sela lipatan rotan, yang memakan rotan itu sampai lapuk. Di alam bebas, makin lama rotan alami semakin sulit diperoleh, sebagai dampak makin berkurangnya hutan di Indonesia. 
Rotan sintetis tampil sangat natural, memiliki tekstur sebagaimana rotan asli. Rotan sintetis memiliki daya tahan yang cukup tinggi terhadap sinar matahari langsung, hujan, dan perubahan cuaca panas dingin. Selain itu juga tahan terhadap kelembaban, air laut, maupun air yang mengandung klorin, sehingga dapat dicuci. Dibuat dari bahan yang tidak mengandung racun maupun logam berat dan dapat didaur ulang sehingga ramah lingkungan.
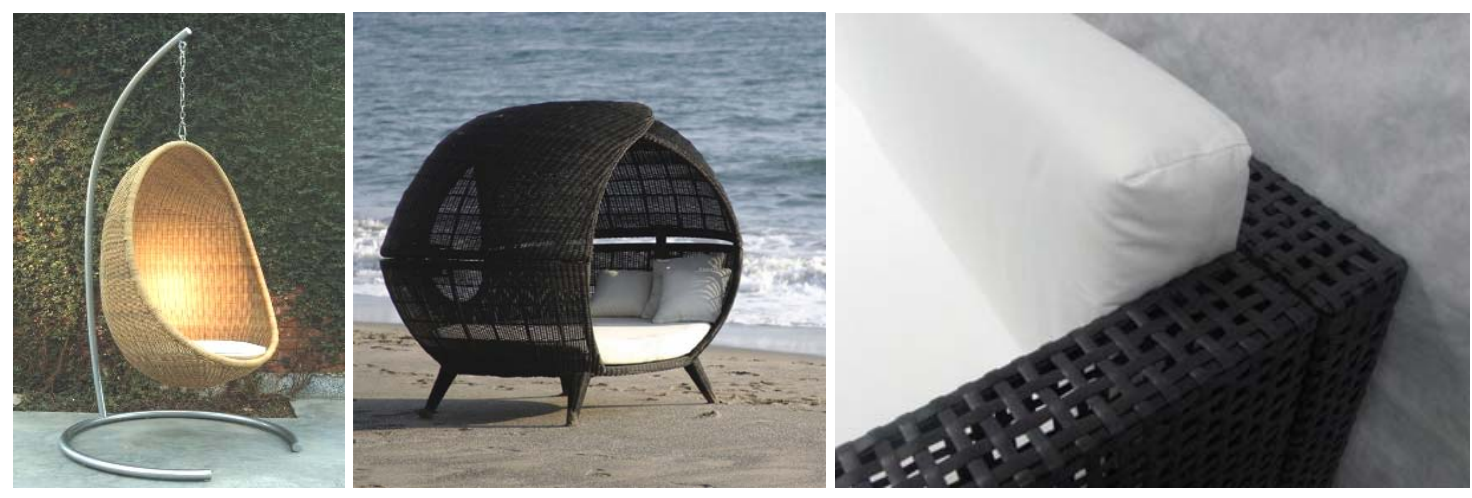

Gambar 10. Contoh Furniture Menggunakan Rotan Sintetis

Oleh sebab itu, rotan sintetis sekarang ini banyak dipilih sebagai material subsitusi untuk material alami rotan. Permintaan terhadap rotan sintetis juga terus meningkat dengan banyaknya alternatif warna, motif, bentuk, dan ketebalannya.

\section{PENUTUP}

Rotan merupakan produk hasil hutan bukan kayu yang berperan penting dalam meningkatkan pendapatan masyarakat sekitar hutan. Peran Indonesia sebagai produsen utama rotan, kini bukan lagi sebagai pemasok bahan baku bagi industri mebel rotan di luar negeri, tetapi sudah beralih menjadi pemasok mebel rotan dan barang kerajinan. Laju pemanenan yang begitu cepat perlu diimbangi dengan upaya pelestarian berupa pemanenan dan efisiensi pemanfaatan. Hal tersebut sangat diperlukan agar kesinambungan pasokan bahan baku terjamin. Selain itu, perlu dilakukan pemahaman potensi hutan yang tersedia melalui pengenalan dan pemanfaatan jenis-jenis rotan yang terdapat di Indonesia. Dari 306 jenis rotan yang terdapat di Indonesia baru 51 jenis saja yang dimanfaatkan secara komersial. Proses pengolahan rotan yang dilakukan di industri rotan pada umumnya sudah baku, yaitu penggorengan, penggosokan dan pencucian, pengeringan, pengasapan dan pengawetan. Berbagai upaya penyempurnaan tiap tahap proses pengolahan telah dilakukan agar kualitas produk rotan meningkat.

Alih teknologi dalam proses pengolahan dapat diberikan kepada masyarakat pedalaman atau daerah untuk meningkatkan mutu yang dihasilkan dan menghindari kerusakan yang lebih besar akibat serangan jamur dan penggerek rotan. Untuk mencukupi kebutuhan rotan yang bermutu perlu pengenalan jenis-jenis rotan yang kurang awet tetapi perlu diawetkan terlebih dahulu disertai teknologi pengolahan yang tepat. Campur tangan pihak instansi penelitian untuk mendukung penyuluhan dan alih teknologi perlu diperluas secara intensif. Kedepannya, segala bentuk kekurangan yang ada pada bahan alami rotan kiranya dapat ditanggulangi dengan kemajuan teknologi dan pengetahuan yang ada. Sehingga penggunaan bahan rotan sintetis tidak hanya sebagai bahan material pengganti terhadap kekurangan dari bahan rotan alami, tetapi dapat menjadi material pelengkap dan pendukung yang bersama-sama dapat menjual dan membawa nilai yang lebih baik lagi terhadap potensi pengrajin dan 
pecinta rotan baik di dalam maupun luar negeri. Selain itu, pembinaan masyarakat daerah atau pedalaman dalam pengolahan rotan juga perlu ditingkatkan, terutama di dunia Desain Interior dalam pembuatan furniture dan accessories. Dengan meningkatnya kreativitas pengolahan bahan baku rotan tersebut diharapkan dapat meningkatkan taraf kehidupan masyarakat sekitar serta membawa kemajuan Bangsa Indonesia baik di mata Bangsa sendiri ataupun dunia akan potensi sumber daya alam dan manusia yang dimiliki.

\section{DAFTAR PUSTAKA}

Erwinsyah. (1999). Kebijakan Pemerintah dan Pengaruhnya Terhadap Pengusaha Rotan di Indonesia. Diakses dari http://pdf.usaid.gov/pdf_docs/PNACM598.pdf

http://rotanindonesia.yolasite.com/pustaka-rotan.php. Diakses pada tanggal 30 Januari 2012.

http://rotanindonesia.yolasite.com/pustaka-rotan.php. Diakses pada tanggal 30 Januari 2012.

http://www.dephut.go.id/files/Sari Hasil Penelitian Rotan . pdf. Diakses pada tanggal 30 Januari 2012.

Januminro. (2000). Rotan Terpenting Indonesia.

Januminro. (2000). Sebaran Populasi dan Prosentase Pohon Rotan Di Indonesia.

Januminro. (2005). Rotan Indonesia, Potensi Budi Daya Pemungutan, Pengolahan, Standar Mutu dan Prospek Pengusahaan. Kanisius. Yogjakarta.

Januminro. (2009). Keindahan Rotan Indonesia, Cara Mudah Membuat Anyaman dan Meubel Rotan. Kanisius. Yogjakarta.

Jasni, Martono, dan Supriana, Nana. Sari Hasil Penelitian Rotan. 